\title{
Study on indigenous food processing practices among Banjara women
}

\author{
SHITAL RATHOD \\ All India Coordinated Research Project, Department of Home Science Extension and \\ Communication Management, College of Home Science, Vasantrao Naik Marathwada \\ Krishi Vidyapeeth, PARBHANI (M.S.) INDIA \\ (Email : shitalv26@yahoo.com)
}

\begin{abstract}
The investigation was carried out to identify the processed foods prepared by the Banjara women. The indigenous practices for preparation of these foods were also documented. The study was carried out in Pusad Panchayat Samiti of Yavatmal district of Maharashtra state. For the study, 4 villages were selected viz., Devthana, Bori, Limbi and Aregaon. Many Banjara tandas are situated in these villages and they are scattered. Totally 120 Banjara women veterans (old age women) were selected for the study. After identification of the practices the inventory was made to document the indigenous food practices. Chilwa, Dalya, Fla, Chemotyar Batti, Papda, Soji, Muthia, Salai, Thapda, Khardya, Pindya, Lapsi , Lapda, Kurde, Shengolya, Galwali, Shav, Laptti, Laptti Sar, Wda, Ghugrya, Chola were the indigenous processed foods identified. In the second instance, the indigenous food processing practices of the Banjara community were identified and documented. After identification of the practices, it was concluded that most of the respondents had medium level of knowledge about food processing practices as they were far away from the traditional old indigenous practices.
\end{abstract}

KEY WorDS : Indigenous knowledge, Processed food, Banjara women

View Point Article : Rathod, Shital (2014). Study on indigenous food processing practices among Banjara women. Internat. J. Home. Sci. Extn. \& Comm. Mgmt., 1 (2): 57-62

Article History : Received : 20.01.2014; Revised : 03.05.2014; Accepted : 18.05.2014 